International Research Journal of Management, IT \& Social Sciences
Available online at https://sloap.org/journals/index.php/irjmis/
Vol. 6 No. 6, November 2019, pages: 172 177
ISSN: 2395-7492
https://doi.org/10.21744/irjmis.v6n6.789

\title{
Selfie Tourism Promotion to Support Innovative Tourism in the Era of Disruption
}

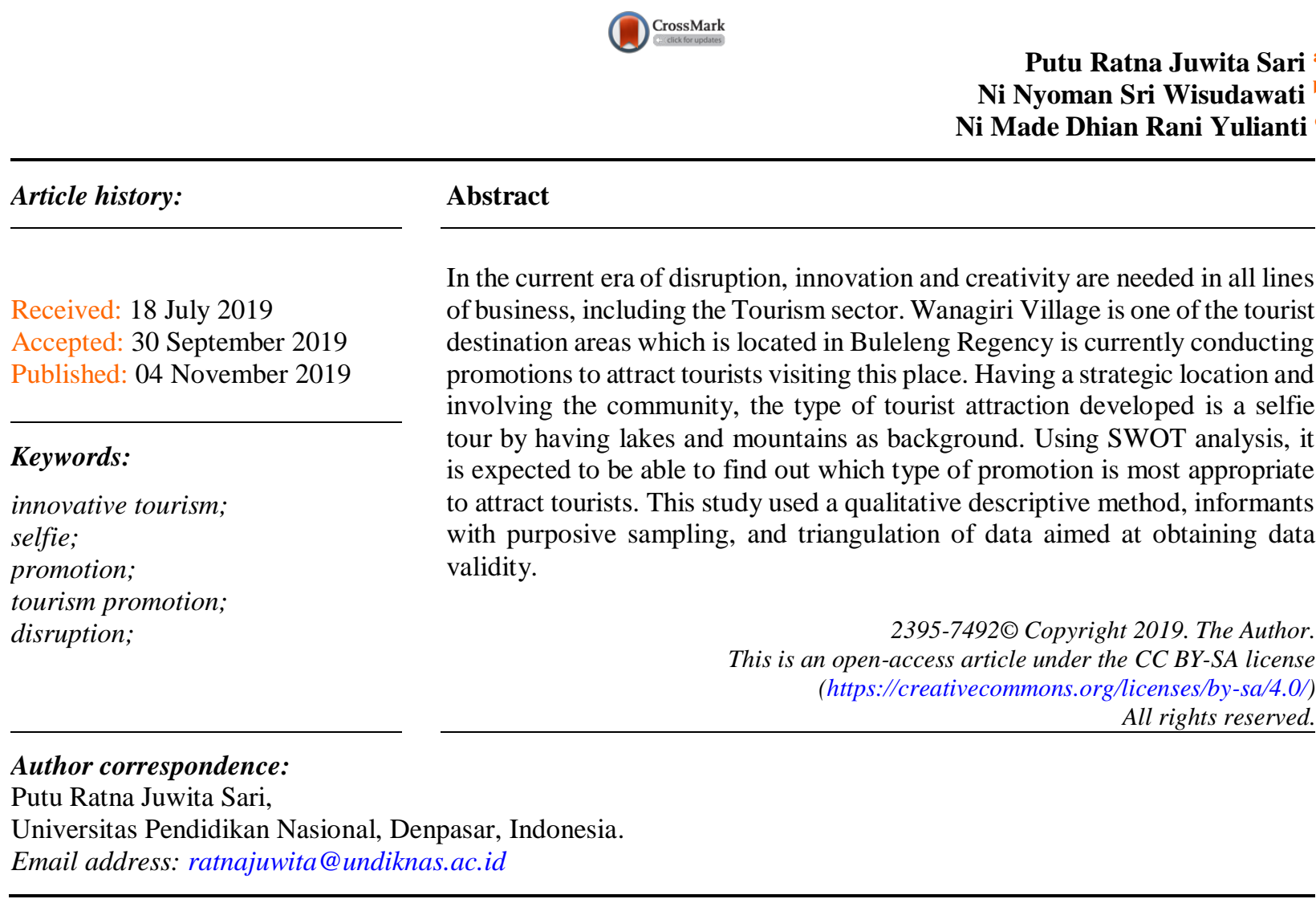

\section{Introduction}

The culture and natural scenery are the main reason why tourists come to visit Bali. This combination makes Bali a leading tourism destination not only in Indonesia but also throughout the world. The tourism sector itself has differences in the distribution of tourist numbers, where the Regional Original Revenue (PAD) of the tourism sector in the South Bali region is far above the PAD of the North Bali region. Thus it is deemed necessary to develop innovate and promote tourism in North Bali, precisely in the Regency of Buleleng, which also has unique cultural and natural charm (Putra, 2015).

One of the innovations of a tourism destination is the main and supporting attraction given to tourists (Anom, 2010; Martono, 2012). The intended innovation is a new, creative effort, effort or strategy that can be implemented in attracting tourists to come to a tourist destination. This creative effort is highly needed considering the tourism potential of Buleleng Regency is very high but rarely visited because it has not been arranged optimally and the lack of

${ }^{a}$ Universitas Pendidikan Nasional, Denpasar, Indonesia

b Universitas Pendidikan Nasional, Denpasar, Indonesia

${ }^{\mathrm{c}}$ Universitas Pendidikan Nasional, Denpasar, Indonesia 
promotion. Tourism developed is community-based, so the government should have synergized better with the community and the management of the tourist destination, it would provide results regarding the expectations

Morcardo (2003) in Utama (2017), that sustainable tourism development can be seen from two points of view, namely the quality in which sustainable tourism development is expected to provide a quality travel experience for tourism and contribution to the quality of life of people in tourism destinations concerned as the host, and also maintain or improve the quality of the intended tourism destination environment. The second perspective is sustainability which means that tourism is designed in such a way so that it can provide guarantees for the sustainability of natural and cultural resources used as attractions, the sustainability of community support and the continuation of tourists' desires to visit the relevant tourism destinations (Hidayatulloh, 2011; Nazir, 2014).

One of the tourist destinations that use the model of sustainable tourism development and is being visited by lot is the Village of Wanagiri, Buleleng Regency located on a strategic route near the Bedugul tourist area (Putra \& Campbell, 2015; Sumadi, 2016). The type of alternative tourism that is currently developing in the village of Wanagiri is a place to take selfies with a background of mountains and lakes, as well as additional creations of each place such as swings, bird nests, etc.

Selfie tourism which is now still developing requires a marketing strategy to increase the number of tourists and to avoid competition from other regions that also develop similar businesses. Promotion is considered as one part of the marketing mix that is necessary to be developed. There is an era of disruption that demands changes quickly, then the promotion strategy that must be done is contemporary and quickly changes in accordance with the demands of tourists. As for the purpose of this study is to know and provide a clear picture of the strategy of promoting tourist attraction in order to be of interest and have a higher value compared to other areas that have selfie tourist properties (Widiastini, 2012; Wening et al., 2014; Suniastha Amerta, 2017).

\section{Materials and Methods}

This research uses the descriptive qualitative method by taking the location of the study in Wanagiri Village, Buleleng Regency this location was used because this place has a potential attraction that has not been optimally packaged and managed by the local community. The type of data used were primary data such as in-depth interviews and questionnaires and secondary data such as the number of visitors and theoretical studies used to complete the data. Data collection techniques were carried out by means of in-depth observation, in-depth interviews, questionnaire distribution and documentation (Ikhsan \& Pertanian, 2011). Analysis of the data used in this study to use a SWOT analysis that aimed to identify the strengths and weaknesses of tourist destinations, while macro analysis purposed to identify opportunities and threats for tourist destinations and to determine the right strategy in developing selfie tourism destinations in the village of Wanagiri.

\section{Results and Discussions}

a) The following is the calculation of the results of an internal strategic factor analysis of the Wanagiri village selfie tourism destination consisting of strengths and weaknesses, through the identification of the IFAS table (internal factor strategy):

Table 1

IFAS calculation results

\begin{tabular}{|c|c|c|c|c|c|}
\hline No & Internal Strategy Factor & Weight & Rating & Score & Comment \\
\hline \multicolumn{6}{|c|}{ STRENGHT } \\
\hline 1 & $\begin{array}{l}\text { The natural beauty that is } \\
\text { interesting and has the } \\
\text { characteristics of a tourist } \\
\text { destination }\end{array}$ & 0.19 & 4 & 0.72 & $\begin{array}{l}\text { The potential of nature tourism in the } \\
\text { village of Wanagiri is beautiful and has a } \\
\text { unique natural landscape }\end{array}$ \\
\hline 2 & $\begin{array}{l}\text { Very strategic location and } \\
\text { easy to reach }\end{array}$ & 0.19 & 4 & 0.74 & $\begin{array}{l}\text { Tourist sites that are often passed by } \\
\text { vehicles and are the main route to Buleleng } \\
\text { regency }\end{array}$ \\
\hline
\end{tabular}

Sari, P. R. J., Wisudawati, N. N. S., \& Yulianti, N. M. D. R. (2019). Selfie tourism promotion to support innovative tourism in the era of disruption. International Research Journal of Management, IT and Social Sciences, 6(6), 172-177. https://doi.org/10.21744/irjmis.v6n6.789 


\begin{tabular}{|c|c|c|c|c|c|}
\hline 3 & $\begin{array}{l}\text { The location is close to other } \\
\text { natural tourism potentials } \\
\text { such as the Wanagiri } \\
\text { waterfall. }\end{array}$ & 0.18 & 3 & 0.64 & $\begin{array}{l}\text { There are alternative choices of other } \\
\text { tourist destinations that are close to } \\
\text { Wanagiri selfie tourism sites }\end{array}$ \\
\hline 4 & $\begin{array}{l}\text { The price of the ticket is } \\
\text { affordable }\end{array}$ & 0.17 & 4 & 0.58 & $\begin{array}{l}\text { Affordable prices for all tourists and non- } \\
\text { tourists alike }\end{array}$ \\
\hline \multirow{2}{*}{\multicolumn{2}{|c|}{$\begin{array}{l}\text { Sub Total } \\
\text { WEAKNESSES }\end{array}$}} & 0.73 & & 2.68 & \\
\hline & & & & & \\
\hline 1 & $\begin{array}{l}\text { Inadequate supporting } \\
\text { facilities }\end{array}$ & 0.06 & 1 & 0.08 & $\begin{array}{l}\text { There is no parking area for tourist } \\
\text { destinations so that it disturbs public roads, } \\
\text { the absence of public toilets and proper } \\
\text { waiting lounge. }\end{array}$ \\
\hline 2 & $\begin{array}{l}\text { Lack of professional Human } \\
\text { Resources in tourism and } \\
\text { marketing }\end{array}$ & 0.11 & 2 & 0.23 & $\begin{array}{l}\text { Required Human Resources who } \\
\text { understand the standards service, tourism } \\
\text { activities safety and appropriate marketing. }\end{array}$ \\
\hline 3 & $\begin{array}{l}\text { Promotion strategy is not } \\
\text { optimal yet }\end{array}$ & 0.10 & 2 & 0.20 & $\begin{array}{l}\text { Lack of promotional activities, only relying } \\
\text { on word of mouth promotions and posts } \\
\text { from tourists on private social media (not } \\
\text { from the manager of Wanagiri's "Selfie" } \\
\text { travel destination) }\end{array}$ \\
\hline \multicolumn{2}{|c|}{ Sub Total } & 0.27 & & 0.51 & \\
\hline \multicolumn{2}{|c|}{ Total } & 1.00 & & 3.19 & \\
\hline
\end{tabular}

Table 2

EFAS calculation results

\begin{tabular}{|c|c|c|c|c|c|}
\hline No & Internal strategy factors & Weight & Rating & Score & Comment \\
\hline \multicolumn{6}{|c|}{ OPPORTUNITIES } \\
\hline 1 & $\begin{array}{l}\text { "selfie" tourism is very } \\
\text { popular nowadays }\end{array}$ & 0.18 & 4 & 0.64 & $\begin{array}{l}\text { The development of tourism currently leads } \\
\text { to the trend of social media content by } \\
\text { targeting photo spots or tourist attractions } \\
\text { that are trending or viral }\end{array}$ \\
\hline 2 & $\begin{array}{l}\text { The rapid development of } \\
\text { technology and } \\
\text { information channels } \\
\text { (through social media) }\end{array}$ & 0.12 & 3 & 0.31 & $\begin{array}{l}\text { The era of revolution } 4.0 \text { has accelerated the } \\
\text { flow of information through technology and } \\
\text { social media }\end{array}$ \\
\hline 3 & $\begin{array}{l}\text { Support from the local } \\
\text { community }\end{array}$ & 0.16 & 3 & 0.54 & $\begin{array}{l}\text { Management is carried out directly by the } \\
\text { local community }\end{array}$ \\
\hline 4 & $\begin{array}{l}\text { The purchasing power of } \\
\text { tourists is quite high }\end{array}$ & 0.16 & 3 & 0.55 & $\begin{array}{l}\text { Strategic location and low ticket prices that } \\
\text { makes the buying interest of tourists high }\end{array}$ \\
\hline & & 0.62 & & 2.04 & \\
\hline \multicolumn{6}{|c|}{ THREATS } \\
\hline 1 & $\begin{array}{l}\text { Competitiveness with } \\
\text { competitors of similar } \\
\text { products is increasing }\end{array}$ & 0.09 & 2 & 0.18 & $\begin{array}{l}\text { Similar tourist attractions have begun to } \\
\text { develop in various regions both inside and } \\
\text { outside the district of Buleleng with the } \\
\text { rapid flow of information through social } \\
\text { media }\end{array}$ \\
\hline 2 & $\begin{array}{l}\text { Domestic and foreign } \\
\text { political conditions }\end{array}$ & 0.09 & 2 & 0.18 & $\begin{array}{l}\text { The current domestic political conditions are } \\
\text { still unstable }\end{array}$ \\
\hline 3 & $\begin{array}{l}\text { Environmental damage due } \\
\text { to human activities }\end{array}$ & 0.09 & 2 & 0.15 & $\begin{array}{l}\text { The location of the construction of this tour } \\
\text { is a protected location and has collaborated } \\
\text { with the Natural Resources Conservation } \\
\text { Center (BKSDA), but the low public }\end{array}$ \\
\hline
\end{tabular}


4

4 Competitive tourist destinations that have been managed more professionally

Sub Total

Total
$0.11 \quad 2$

0.38

1.0 awareness of the discipline by throwing garbage in its place.

By the development of several similar selfie tourist destination locations in several areas have been professionally managed and in accordance with standards for tourism

Based on the IFAS calculation table, the analysis results showed the strength factor obtained a score of 2.68 and a weakness of 0.51 . So the difference in the score $(+)$ is 2.17 while the EFAS table shows that the chance factor gets a score of 2.04 while the threat is 0.74 with the difference in external factors of $(+) 1.30$.

b) Selfie Tourism Promotion Strategy in Wanagiri Village

Based on the IFAS and IFAS tables and the SWOT analysis, the promotional strategies that can be carried out by Wanagiri Village are as follows:

Table 3

Selfie Promotion Strategy in Developing Innovative Tourism in Wanagiri Village

\begin{tabular}{|c|c|c|}
\hline EFAS & $\begin{array}{l}\text { Strength (S): } \\
\text { 1. The natural beauty that is interesting and } \\
\text { has the characteristics of a tourist } \\
\text { destination } \\
\text { 2. Very strategic location and easy to reach } \\
\text { 3. The location is close to other natural } \\
\text { tourism potentials such as the Wanagiri } \\
\text { waterfall. } \\
\text { 4. The price of the ticket is affordable }\end{array}$ & $\begin{array}{l}\text { Weaknesses }(\mathbf{W}) \\
\text { 1. Inadequate supporting facilities } \\
\text { 2. Lack of professional Human Resources } \\
\text { in tourism and marketing } \\
\text { 3. Promotion strategy is not optimal yet }\end{array}$ \\
\hline $\begin{array}{l}\text { Opportunities }(\mathbf{O}) \\
\text { 1. "selfie" tourism is } \\
\text { very popular } \\
\text { nowadays } \\
\text { 2. The rapid } \\
\text { development of } \\
\text { technology and } \\
\text { information } \\
\text { channels (through } \\
\text { social media) } \\
\text { 3. Support from the } \\
\text { local community } \\
\text { 4. The purchasing } \\
\text { power of tourists is } \\
\text { quite high }\end{array}$ & $\begin{array}{l}\text { SO Strategies: } \\
\text { 1. Maintain Wanagiri as a selfie tourist } \\
\text { destination with special characters such } \\
\text { as a beautiful natural resource and } \\
\text { strategic location by using technology to } \\
\text { spread out the information and it became } \\
\text { a brand image of a unique selfie tourist } \\
\text { destination in Bali. } \\
\text { 2. Development of tourist destinations that } \\
\text { further enhanced by the participation of } \\
\text { local communities starting from } \\
\text { planning, management, and supervision }\end{array}$ & $\begin{array}{l}\text { WO Strategies: } \\
\text { 1. Improving supporting facilities such as } \\
\text { toilets, parking lots, trash cans for the } \\
\text { convenience of tourists } \\
\text { 2. Improve the quality of human resources } \\
\text { through training and counseling related } \\
\text { to management and workers in the field } \\
\text { in accordance with standards. } \\
\text { 3. Increasing the promotion of tourist } \\
\text { destinations through the creation of an } \\
\text { official account of Wanagiri self- } \\
\text { tourism destinations through social } \\
\text { media (IG, FB, etc.) and websites. } \\
\text { 4. Creating interesting and creative } \\
\text { content in the form of photos and } \\
\text { facilities in Wanagiri selfie destinations } \\
\text { before uploaded to social media. }\end{array}$ \\
\hline $\begin{array}{l}\text { Threat }(\mathbf{T}) \\
\text { 1. Competitiveness } \\
\text { with competitors }\end{array}$ & $\begin{array}{l}\text { ST Strategies: } \\
\text { 1. In the development of selfie tourism } \\
\text { destinations in Wanagiri to pay attention }\end{array}$ & $\begin{array}{l}\text { WT Strategies: } \\
\text { By more actively promoting through social } \\
\text { media and increasing the quality of tourist }\end{array}$ \\
\hline
\end{tabular}

Sari, P. R. J., Wisudawati, N. N. S., \& Yulianti, N. M. D. R. (2019). Selfie tourism promotion to support innovative tourism in the era of disruption. International Research Journal of Management, IT and Social Sciences, 6(6), 172-177. https://doi.org/10.21744/irjmis.v6n6.789 


\begin{tabular}{|c|c|c|c|}
\hline $\begin{array}{l}\text { of similar products } \\
\text { is increasing } \\
\text { 2. } \begin{array}{l}\text { Domestic and } \\
\text { foreign political } \\
\text { conditions }\end{array} \\
\text { 3. } \begin{array}{l}\text { Environmental } \\
\text { damage due to } \\
\text { human activities }\end{array} \\
\text { 4. Competitive } \\
\text { tourist } \\
\text { destinations that } \\
\text { have been } \\
\text { managed more } \\
\text { professionally }\end{array}$ & & $\begin{array}{l}\text { to certain spots that can be managed and } \\
\text { developed as selfie tourism destinations } \\
\text { through cooperation with BKSDA to } \\
\text { avoid exploitation of natural resources } \\
\text { in the area so as to reduce the natural } \\
\text { damage that can be caused. } \\
\text { Creating a program or classifying } \\
\text { marketing (segmentation, target and } \\
\text { market position) through a tourism } \\
\text { program that is able to compete with } \\
\text { similar tourism destinations without } \\
\text { ignoring the importance of nature and } \\
\text { conservation-based management for its } \\
\text { sustainability. }\end{array}$ & $\begin{array}{l}\text { attraction products with the characteristics } \\
\text { they have consistently in environmentally } \\
\text { friendly management, Wanagiri "selfie" } \\
\text { tourist destinations can face competitors of } \\
\text { similar products that develop in other areas } \\
\text { especially outside the regency of Buleleng. }\end{array}$ \\
\hline
\end{tabular}

\section{Conclusion}

The selfie or selfie tourist attraction is in quadrant I which illustrates the situation that occurs in the tourist attraction is very good with the use of force to achieve profitable opportunities. Thus an alternative strategy for aggressive marketing development can be used. Based on the SWOT analysis, four alternatives can be carried out on the selfie tourist attraction in the village of Wanagiri. There are three essential points that can be drawn from the research as follows:

a) Formulation of a promotion strategy of attraction for selfie tourism in Wanagiri village The promotion strategy consists of promotion mix and target market can be concluded that the target market for self-guided tourism attractions comes from all groups of both domestic and foreign tourists who cross the Wanagiri self-guided tourism attraction.

b) SWOT Analysis Result

The results of the Wanafiri village self-tourism tour attraction are in quadrant I which shows that this selfpowered tourism attraction has the power and opportunity in the market.

c) The next step in decision making

Marketing strategies can be done through SO strategies by utilizing existing strengths and opportunities. Efforts can be made related to promotions, for example by creating an official account of Wanagiri self-tourism destinations through social media (IG, FB, etc.) and websites and creating interesting and creative content in the form of photos and facilities in Wanagiri self-catering destinations that are uploaded to social media.

\section{Conflict of interest statement}

The authors declared that they have no competing interests.

\section{Statement of authorship}

The authors have a responsibility for the conception and design of the study. The authors have approved the final article.

\section{Acknowledgments}

The authors would like to thank the reviewer for their consideration of the further process of the present paper. Thanks to the editor of IRJMIS for the valuable support, time as well as advice. 


\section{References}

Anom, I. P. (2010). Pariwisata Berkelanjutan dalam Pusaran Krisis Global. Denpasar Udayana.

Hidayatulloh, Yayat Nasrulloh. 2011. Strategi Pemasaran Objek Wisata Alam Talaga Remis di Taman Nasional Gunung Ciremai. Fakultas Kehutanan Institut Pertanian Bogor.

Ikhsan, S., Aid, A., \& Pertanian, S. P. J. S. E. (2011). Analisis SWOT untuk merumuskan strategi pengembangan komoditas karet di Kabupaten Pulang Pisau, Kalimantan Tengah. Jurnal Agribisnis Pedesaan, 1(3), $166-177$.

Martono, N. (2012). Sosiologi Perubahan Sosial: Perspektif Klasik, Modern, Posmodern, dan Poskolonial (Sampel halaman). RajaGrafindo Persada Jakarta.

Moscardo, G. (2003). Interpretation and sustainable tourism: functions, examples and principles.[Reprint of original article published in v. 9, no. 1, 1998: 2-13.]. Journal of tourism studies, 14(1), 112.

Nazir, M. (2014). Metode Penelitian Cet. 9. Penerbit Ghalia Indonesia. Bogor.

Putra, I. N. D. (Ed.). (2015). Pariwisata berbasis masyarakat model Bali. Buku Arti.

Putra, I. N. D., \& Campbell, S. L. (Eds.). (2015). Recent Developments in Bali Tourism: Culture, Heritage, and Landscape in an Open Fortress. Program Studi Magister Kajian Pariwisata, Universitas Udayana.

Sumadi, K. (2016). Tourism development basis in traditional village of Kuta. International Journal of Linguistics, Literature and Culture, 2(3), 124-132

Suniastha Amerta, I. M. (2017). The role of tourism stakeholders at Jasri tourism village development, Karangasem regency. International Journal of Social Sciences and Humanities, 1(2), $20-28$. https://doi.org/10.29332/ijssh.v1n2.32

Utama, I. G. B. R. (2017). Pemasaran Pariwisata. Penerbit Andi.

Wening, N., Al Hasny, M., \& Fitryana, R. (2014). Strategi Pemasaran Untuk Meningkatkan Jumlah Kunjungan Pada Obyek Wisata Kebun Raya Dan Kebun Binatang (KRKB) Gembira Loka Di Kota Yogyakarta. Kajian Bisnis STIE Widya Wiwaha, 22(1), 1-10. https://doi.org/10.32477/jkb.v22i1.193

Widiastini, N. M. A. (2012). Strategi Pemasaran Pariwisata Di Kabupaten Buleleng, Bali. Jurnal Ilmu Sosial dan Humaniora, 1(1).

Sari, P. R. J., Wisudawati, N. N. S., \& Yulianti, N. M. D. R. (2019). Selfie tourism promotion to support innovative tourism in the era of disruption. International Research Journal of Management, IT and Social Sciences, 6(6), 172-177. https://doi.org/10.21744/irjmis.v6n6.789 